\title{
Investigating Turkish Pre-service Teachers' Perceptions of Blogs: Implications for the FATIH Project
}

\author{
Mehmet Akif Ocak, Şahin Gökçearslan, \& Ebru Solmaz \\ Gazi University, Turkey
}

\begin{abstract}
This study aimed to investigate pre-service teachers' perceptions on the use of blogs regarding ICT integration in the FATIH project in Turkey. Participants were 174 pre-service teachers continuing their education. Data collection tool was a questionnaire which measured pre-service teachers' perceptions of the blogs. Questionnaire embodied some sub-categories of blog use such as learning, motivation, active participation, writing skills, group work, and critical thinking. Findings revealed that using blogs in classes affected learning and teaching process. The obtained results also showed that the blogs contributed to the recuperation of writing and critical thinking skills. These results indicated that students found social contributions of the blogs such as sharing information and interacting with peers. Based on the findings of study, appropriate conclusions and implications were addressed within the context of the FATIH project.
\end{abstract}

Keywords: Blogs; FATIH project; Tablet computers; Technology use in education; Technology integration

\section{Introduction}

The Internet is a communication tool, through which people interact socially. Since the World Wide Web was created, the diffusion rate of the Internet was greater than the diffusion rate of any other communication technology, and the Internet has become the fastest spreading communication tool of the history (Slevin, 2000). The development of the web is addressed in four stages according to the "Semantic Wave Research Report". While the first stage, namely Web 1.0, enabled connection to network and access to information, Web 2.0 aimed to enable social interaction among people (Davis, 2008). The term "Web 2.0" was used to refer to the new period and conception in the brainstorming conference "Media Live International" in 2004; and the second-generation web included various web activities such as wiki, blog, and search engine optimization (O'Reilly, 2007). Web 2.0 provides a social approach for cooperation in order to produce, share and reuse, and it includes new applications. Web 2.0 activities, like blogs and forums, enhance online cooperation and sharing between learners (Martinez \& Jagannathan, 2010).

The literature indicates that as ICT tools become very common in teaching process, it will force teachers to adapt these technologies to their instruction (Dursun, Kuzu, Kurt, Güllüpınar, \& Gültekin, 2013). In this sense, in the Movement of Enhancing Opportunities and Improving Technology (FATIH) project of Turkey, teachers play important role to execute the project since safe, manageable, and measurable ICT use is required in classrooms. The literature suggests that perceptions of teachers on technology integration should be examined deeply when the 
integration of computer applications in the FATIH project come forward (Kurt, Kuzu, Dursun, Güllüpınar, \& Gültekin, 2013). Accordingly, the purpose of this study is to further examine preservice teachers' perceptions of blogs in regard to ICT integration of the FATIH project.

\section{Weblogs}

\section{Definition of Blogs}

Blogs are basically personal web pages in the form of logs. Although the formats of blogs are similar to each other, they include different and various topics such as politics, technology, daily events, culture, entertainment, hobbies and interests (Oreilly, 2007; Rice, 2003). The term "blog", which is derived from the word Weblog, refers to a log in virtual environment. Blogs are personal pages where the sent messages are listed from top to down in reverse chronological order, and they are frequently updated and usually focused on a specific topic. The name of the writer and the date of the entry are usually indicated at the end of each entry in blogs. Any Internet user may read a blog and add his/her own comment (Rice, 2003). Commenting on a published message requires the permission of the sender of the message. The most important dynamics of the blog culture include commenting on the published messages as well as the viewing and replying of the comments, so that feedback-based communication is provided between the senders and receivers of the messages. Interaction is the key for the popularity of blogs.

\section{Advantages of Blogs}

Creating a webpage is a prominent feature of blogs. Although tools such as HTML editors and FTP clients enable many teachers and students to use web publishing, the difficulty of learning how to use these tools constitutes a barrier to web publishing for many people (Duffy \& Bruns, 2006; Martindale \& Wiley, 2004). Blog interface, which makes it possible to enter and present information in a blog, facilitates web publishing (Duffy \& Bruns, 2006; Efimova \& Moor, 2005), so that blogs significantly reduce the barriers to web publishing especially for beginners (Duffy \& Bruns, 2006; Martindale \& Wiley, 2004).

Blogs are excellent tools for educators as they can be easily used and accessed anytime and anywhere. Considered as an efficient educational technology, learning environment in blogs is not limited to the classroom; the developers can create their blogs at any place where there is access to the Internet (Churchill, 2009; Huffaker, 2005). Regardless of technology, blogs can be created by using any computer, labtop, tablet computers, and cell phones in which only Internet access is needed.

Blogs are also very useful tools for learning and teaching as they provide a space where students can publish their ideas. The readers can make comments in the blogs and thus they have the opportunity to get feedback and acquire new ideas. By providing connections, blogs enable the students to communicate with their peers, experts, professionals, teachers and others. Blogs provide the students with the opportunity to actively learn, express, and spread their ideas, thoughts and feelings (Wang, 2009). They also provide interaction through personal news, opinions, and ideas (Duffy \& Bruns, 2006; Ferdig \& Trammell, 2004). In these environments which can be named as "learning by writing" environments, students can write any information in the form of notes, increase their awareness about the topic in the process 
of writing, and create new products. Blogs, which are social software, can be frequently used to expand communication environments (Kim, 2008). According to Richardson (2006), the contributions of the blogs include:

- motivating students

- increasing communication and interaction among students

- providing an opportunity for group works

- expressing and developing the ideas of learners

- getting feedback from others

- improving analytical, critical, creative, and intuitive thinking

- working on actual duties

- enriching learning environments

- developing learning activities

- developing skills

- developing high-level thinking skills

- merging individual and social interaction.

Teachers can use blogs to create an environment where students will feel themselves as an important part of the class and where their ideas and needs are recognized and addressed. Moreover, the use of blogs as a platform can provide more opportunities for the students to make comments and criticize the ideas of other students, when compared to classroom environment (Churchill, 2009). It was also revealed through various studies that blogs improve writing skills (Arslan \& Kızıl, 2010; Jones, 2006; Kenndey, 2003).

Blog applications are in the Internet environment accessed in any computer tool (tablet, notebook etc.), which significantly attracts the attention of today's students. The interest of the students in the Internet environment is reinforced by blog applications, which are a part of such environment. It is explicit that students prefer interactive learning environments like blogs, which provide flexibility in many aspects, rather than single, static web pages (Şenel \& Seferoğlu, 2009). In addition, it is suggested that teachers also need to create communities and design activities that will allow for online information exchange (Hou, Chang \& Sung, 2011). It is also stated that the use of blogs will help teachers in ensuring the use and integration of information and communication technologies in classrooms. Teachers need to follow such new tools especially in educational context (Duffy \& Bruns, 2006) and the general competences of the profession of teaching include the skills in information and communication technologies (Turkish Ministry of National Education, 2008).

Fullan (1990) indicates that educational change begins with what teachers do and think. Especially, contexts where teachers are being pressured to integrate technology into their instructional activities require a constant commitment to adopt technology. Thus, this process needs further examination of teachers' perceptions about the integration of computer applications as an instructional tool. In this sense, this study aims to determine the views of pre-service teachers about the blog use in terms of integration of technology in the FATIH Project of Turkey.

\section{The FATIH Project}

A project on the use of communication technologies in education was started in Turkey in 2010. This project is called FATIH (Movement to Increase Opportunities and Improving 
Technology), which is defined as the movement of increasing opportunities both for students and teachers and enhancing technology in schools by furnishing the 570.000 classrooms in 42.000 schools with the equipment of information technologies. One of the components of this project is the efficient use of ICT in teaching program (Turkish Ministry of National Education, 2012).

According to Demirel (2010), it was revealed by various studies that teachers and pre-service teachers were not sufficient in terms of using information technologies. Furthermore, "Research Report on Blog Writing in Turkey", a research on the use of blogs, which were considered as an effective educational technology (Churchill, 2009), indicated that the use of blogs for educational purposes was at a low level (24\%) (Girgin, 2009). It can be considered that this situation results from the insufficient use of blogs in educational activities both in the classroom and out of the classroom.

The FATIH project is expected to increase the success of the students by using technology effectively in classrooms. However, investigating the qualification of teachers regarding implementation of the technology seems the most important aspect of the FATIH project. Thus, it is important to investigate whether teachers have the necessary information and skills to be able to use those technologies effectively in the FATIH project.

\section{Research Questions}

The perceptions of pre-service teachers about the educational use of blogs, which are one of the information and communication technologies, will be a guide for the success of ICT integration in the FATIH project and for the design of environments that will enrich learning. The potential use of blogs and various studies (Arslan \& KIzIl, 2010; Churchill, 2009; Duffy \& Bruns, 2006; Ferdig \& Trammell, 2004; Kenndey, 2003; Kim, 2008; Jones, 2006; Richardson, 2006; Şenel \& Seferoğlu, 2009; Wang, 2009) point out the importance of educational use of blogs. Therefore, this study aims to reveal the opinions of pre-service teachers about the use of blogs in ICT integration within the FATIH project and to question the benefits of using blogs perceived by pre-service teachers. The following research questions guided the study:

- What are the perceptions of the Turkish pre-service teachers about the educational use of blogs with regard to ICT integration in the FATIH project?

- What are the perceptions of the Turkish pre-service teachers about future benefits of blogs with regard to ICT integration in the FATIH project?

- Is there a significant difference between male and female pre-service teachers' perceptions towards the educational use of blogs?

- Is there a significant difference between male and female pre-service teachers' perceptions on future benefits of blogs?

\section{Method}

\section{Participants}

The study was carried out with freshman students of Gazi Faculty of Education, Gazi University during Spring Term in 2010-2011. Participants, first-grade students in 6 departments of the 
Faculty, took "Computer II" course which was a compulsory course. There were 174 students from the departments of German Teaching, Arabic Teaching, French Teaching, Primary School Mathematics Teaching, Preschool Teaching and History Teaching. Since the implementation covered a period of 5 weeks, the classes, in which the researchers taught blog use in Computer II, were preferred for the selection of the subjects.

\section{Procedures}

Within the scope of the implementation, students exhibited the work they created individually or in groups (2-3 persons) by using blogs. The implementation lasted for 5 weeks. During the first week, information on blogs was given; and during the remaining 4 weeks, implementation was carried out on the blogs created by the students. In the fourth week of the mentioned course, students were informed about blogs and their uses. During the implementation phase, students were requested to share information and visuals related to the activities carried out in the other subjects of the course and to look into the blogs of their friends and comment on the shared information and visuals. Table 1 shows detailed information on the implementation activity about blogs.

Table 1. Course Schedule

\begin{tabular}{|c|c|}
\hline Weeks & Content \\
\hline Week 4 (4 course hours) & $\begin{array}{l}\text { Blog } \\
\qquad \begin{array}{l}\text { - What is blog? How it is used in education? } \\
\text { - Basic processes } \\
\text { - Creating a blog account } \\
\text { - Updating a blog } \\
\text { - Adding a comment of the blog page of someone }\end{array}\end{array}$ \\
\hline Week 5 ( 1 course hour) & $\begin{array}{l}\text { Computer Aided Education (CAE) Basic concepts I-II } \\
\text { - Each person/group reached a picture, video or link } \\
\text { about CAE from various sources and published them } \\
\text { on the blog }\end{array}$ \\
\hline $\begin{array}{l}\text { At the end of Weeks } 7-10 \text { ( } 1 \text { course } \\
\text { hour) }\end{array}$ & $\begin{array}{l}\text { Software Use in Education } \\
\text { - Each person/group evaluated an educational } \\
\text { software program and published it on the blog. } \\
\text { Groups added comments. }\end{array}$ \\
\hline Week 11 ( 1 course hour) & $\begin{array}{l}\text { Distance Learning } \\
\text { - Each person/group published information from } \\
\text { various resources. }\end{array}$ \\
\hline $\begin{array}{l}\text { At the end of Weeks } 12-14 \text { ( } 1 \text { course } \\
\text { hour) }\end{array}$ & $\begin{array}{l}\text { Database } \\
\text { - Each person/group shared their tables, forms, } \\
\text { relation structures they created on the database } \\
\text { program MS Access. }\end{array}$ \\
\hline
\end{tabular}




\section{Data Collection}

Data were collected through online survey in the classroom after giving information about survey. Surveys were administered to pre-service teachers in a computer lab environment. The survey approximately took 10 minutes to complete. First section of the survey was related to demographic information, the second section of the survey was related to perceptions of preservice teachers in regard to educational use of blogs, and the third section of the survey was related to perceptions of pre-service teachers about future benefits of blog use.

\section{Instrumentation}

An online survey was used as the data collection instrument to get the opinions of pre-service teachers about using blogs for ICT integration in the FATIH project. Survey items were created by reviewing the literature. A review of the literature shows various studies proving that the educational use of blogs have such benefits as improving writing skills (Arslan \& Kızıl, 2010; Jones, 2006; Kenndey, 2003), supporting learning (Churchill, 2009; Richardson, 2006; Şenel \& Seferoğlu, 2009), increasing motivation, developing critical thinking (Cakir, 2013; Richardson, 2006) and providing active participation (Wang, 2009). Considering this information, a 22 -item pool was created and then 5 specialists were consulted. The survey was shaped in line with the feedback of the specialists and 17-item survey was created. The Likert-type items were expressed as strongly agree, agree, neutral, disagree and strongly disagree. The means and standard deviations of each Likert item were provided in Table 2.

Table 2. The Means and Standard Deviations of Likert Items

\begin{tabular}{|c|c|c|c|c|c|c|c|c|c|c|c|c|c|c|c|c|c|}
\hline & 감 & ช & $\stackrel{m}{\sigma}$ & $\dot{\nabla}$ & 늠 & $\mathscr{0}$ & $\hat{\sigma}$ & $\stackrel{\infty}{\sigma}$ & 임 & 음 & $\underset{\sigma}{\vec{\sigma}}$ & 굼 & $\stackrel{m}{\underset{\sigma}{\sigma}}$ & $\underset{\vec{\sigma}}{\vec{\sigma}}$ & $\frac{n}{\sigma}$ & $\begin{array}{l}\stackrel{0}{\sigma} \\
\vec{\sigma}\end{array}$ & 감 \\
\hline 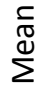 & $\stackrel{\vec{b}}{i}$ & बু & $\begin{array}{l}\stackrel{P}{n} \\
\dot{n}\end{array}$ & 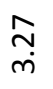 & $\begin{array}{l}\text { 우 } \\
\text { nn }\end{array}$ & $\underset{\sim}{\stackrel{N}{n}}$ & ने & 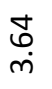 & 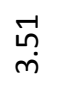 & $\begin{array}{l}\vec{\infty} \\
\dot{n}\end{array}$ & $\begin{array}{l}\mathscr{q} \\
\dot{m}\end{array}$ & $\begin{array}{l}\stackrel{ }{m} \\
\text { r. }\end{array}$ & $\underset{\sim}{\tilde{m}}$ & 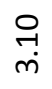 & 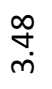 & 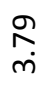 & 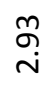 \\
\hline 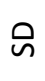 & $\stackrel{\vec{m}}{\rightarrow}$ & $\stackrel{\infty}{\stackrel{\infty}{0}}$ & ஃ্ & $\begin{array}{l}\text { ô } \\
\text { ô }\end{array}$ & تِ & $\underset{\text { İ }}{\text { - }}$ & $\stackrel{\infty}{\infty}$ & જ̆ & $\stackrel{\text { 옴 }}{\text { - }}$ & $\begin{array}{l}\infty \\
\infty \\
0 \\
0\end{array}$ & 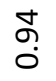 & $\begin{array}{l}\text { ô } \\
\text { Oे }\end{array}$ & 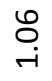 & $\stackrel{\text { O̊ }}{\text { م. }}$ & ֻू & $\begin{array}{l}\text { \% } \\
\text { Oे }\end{array}$ & $\underset{\sim}{\sim}$ \\
\hline
\end{tabular}

The Cronbach's alpha coefficient for 17 items of the scale part of the survey was calculated as .856, indicating that the items had relatively high internal consistency since a reliability coefficient of .70 or higher is generally considered "acceptable" in most social science research situations.

In addition to computing the alpha coefficient of reliability, the dimensionality of the scale was investigated by using factor structure of the tool. It was seen that the eigen value for the four factors is quite a bit larger than the eigen value for the next factors $(5.85,1.56,1.22$, and 1.11 versus other numbers). Additionally, the first factor accounts for $34 \%$ of the total variance. This suggests that the scale items are undimensional (Table 3). 
Table 3. Factor Analysis of the Survey

\begin{tabular}{|c|c|c|c|c|c|c|}
\hline \multirow[t]{3}{*}{ Component } & \multicolumn{3}{|c|}{ Initial Eigenvalues } & \multicolumn{3}{|c|}{ Extraction Sums of Squared Loadings } \\
\hline & & $\%$ of & Cumulative & Total & $\%$ of & Cumulative \\
\hline & Total & Variance & $\%$ & & Variance & $\%$ \\
\hline 1 & 5,85 & 34,41 & 34,41 & 5,85 & 34,41 & 34,41 \\
\hline 2 & 1,56 & 9,20 & 43,61 & 1,56 & 9,20 & 43,61 \\
\hline 3 & 1,22 & 7,17 & 50,79 & 1,22 & 7,17 & 50,79 \\
\hline 4 & 1,11 & 6,53 & 57,32 & 1,11 & 6,53 & 57,32 \\
\hline 5 & 0,95 & 5,64 & 62,96 & & & \\
\hline 6 & 0,92 & 5,43 & 68,40 & & & \\
\hline 7 & 0,79 & 4,66 & 73,06 & & & \\
\hline 8 & 0,62 & 3,66 & 76,73 & & & \\
\hline 9 & 0,59 & 3,505 & 80,23 & & & \\
\hline 10 & 0,57 & 3,379 & 83,61 & & & \\
\hline 11 & 0,54 & 3,232 & 86,84 & & & \\
\hline 12 & 0,46 & 2,733 & 89,58 & & & \\
\hline 13 & 0,43 & 2,556 & 92,13 & & & \\
\hline 14 & 0,40 & 2,406 & 94,54 & & & \\
\hline 15 & 0,35 & 2,07 & 96,61 & & & \\
\hline 16 & 0,31 & 1,83 & 98,45 & & & \\
\hline 17 & 0,26 & 1,55 & 100,00 & & & \\
\hline
\end{tabular}

\section{Data Analysis}

This study is a descriptive research that brings out the opinions of pre-service teachers about the use of blogs. Online surveys were reviewed for any errors and no error was found. Data were ported into the statistical analysis package (SPSS 20) for further analysis. Descriptive analysis using the frequency distribution and percentages, the mean scores and independent group t-test procedures were conducted for the data analysis in order to answer the research questions. While comparing male and female pre-service teachers' responses, mean score differences were taken into account.

\section{Findings}

Following the blog application, the collected data were analyzed through quantitative method. Frequency and percentage values were used in the analysis of each answer to 17 Likert scale items. Distribution of pre-service teachers by gender is shown at Table 4 which shows that 45 participants of the sample are male. 
Table 4. Distribution of Pre-service Teachers by Gender

\begin{tabular}{lll}
\hline Options & $\mathrm{N}$ & $\%$ \\
\hline Male & 45 & 25.86 \\
Female & 129 & 74.14 \\
Total & 174 & \\
\hline
\end{tabular}

Table 5 indicates that students from the preschool teaching program formed the largest subgroup $(27.59 \%)$ in the sample.

Table 5. Distribution of Pre-service Teachers by Their Departments

\begin{tabular}{lll}
\hline Options & $\mathrm{N}$ & $\%$ \\
\hline German Teaching & 27 & 15.52 \\
Arabic Teaching & 19 & 10.92 \\
French Teaching & 19 & 10.92 \\
Elementary School Mathematics Teaching & 28 & 16.09 \\
Preschool Teaching & 48 & 27.59 \\
History Teaching & 33 & 18.97 \\
Total & 174 & 100.00 \\
\hline
\end{tabular}

When the data as to whether the participants had any knowledge about blogs before the application, it appeared that $55.74 \%(\mathrm{~N}=97)$ of them had no preliminary knowledge before the course. This showed that the pre-service teachers had not used blogs in their daily lives or in their past learning activities. Nevertheless, there are Turkish blog services with more than one million members.

Another point addressed was the difficulty level of the use of blogs. According to the results of the research, majority of the students $(82.76 \% ; \mathrm{N}=144)$ reported that they found the use of blogs easy. Only $4 \%$ of the students $(\mathrm{N}=7)$ found it difficult. These bear resemblance to the results of other studies (Göktaş, 2009; Kim, 2007; Tekinarslan \& Gürer, 2011; Yi-Hui, 2013). It can be concluded that blogs can be easily used by everybody without knowledge on web design. This result also reveals that technological tool (tablet, notebook etc.) is not primary requirement as to whether teachers use blogs efficiently.

At the end of the application process, the students were asked for their opinions in various subjects about blogs (learning, motivation, active participation, writing skills, group working, and critical thinking skills). Frequency and percentage distributions pertaining to these opinions are shown in Table 6.

Table 6 demonstrates that $69.54 \%$ of the pre-service teachers $(\mathrm{N}=121)$ think that use of blogs in educational activities contribute to learning. Other studies on this subject have come up with the same findings and similar results (Babur, 2010; West, Wright, Gabbitas \& Graham, 2006; Yang, 2009). In the light of this view, it can be concluded that blogs can be used as an active tool in learning activities before, during and after the lessons. 
Table 6. Opinions of Pre-service Teachers about the Use of Blogs

\begin{tabular}{|c|c|c|c|c|c|c|c|c|c|c|}
\hline & \multicolumn{2}{|c|}{$\begin{array}{c}1 \\
\text { (Totally } \\
\text { Disagree) }\end{array}$} & \multicolumn{2}{|c|}{$\begin{array}{c}2 \\
\text { (Disagree) }\end{array}$} & \multicolumn{2}{|c|}{$\begin{array}{c}3 \\
\text { (Neutral) }\end{array}$} & \multicolumn{2}{|c|}{$\begin{array}{c}4 \\
\text { (Agree) }\end{array}$} & \multicolumn{2}{|c|}{$\begin{array}{c}5 \\
\text { (Totally } \\
\text { Agree) }\end{array}$} \\
\hline & $\%$ & $f$ & $\%$ & $f$ & $\%$ & $f$ & $\%$ & $f$ & $\%$ & $\mathrm{~F}$ \\
\hline $\begin{array}{l}\text { The use of blogs } \\
\text { contributes to my } \\
\text { learning process. }\end{array}$ & 1.72 & 3 & 10.92 & 19 & 17.82 & 31 & 55.17 & 96 & 14.37 & 25 \\
\hline $\begin{array}{l}\text { The use of blogs } \\
\text { increases my motivation } \\
\text { towards courses. }\end{array}$ & 5.17 & 9 & 15.52 & 27 & 33.91 & 59 & 37.93 & 66 & 7.47 & 13 \\
\hline $\begin{array}{l}\text { The use of blogs in } \\
\text { courses enables active } \\
\text { participation in the } \\
\text { courses. }\end{array}$ & 4.02 & 7 & 9.77 & 17 & 17.82 & 31 & 54.60 & 95 & 13.79 & 24 \\
\hline $\begin{array}{l}\text { The use of blogs } \\
\text { contributes to the } \\
\text { improvement of my } \\
\text { writing skills. }\end{array}$ & 5.17 & 9 & 13.22 & 23 & 21.84 & 38 & 45.40 & 79 & 14.37 & 25 \\
\hline $\begin{array}{l}\text { The use of blogs is } \\
\text { effective for group work. }\end{array}$ & 2.30 & 4 & 5.17 & 9 & 18.97 & 33 & 56.32 & 98 & 17.24 & 30 \\
\hline $\begin{array}{l}\text { The use of blogs } \\
\text { improves my critical } \\
\text { thinking skills. }\end{array}$ & 4.02 & 7 & 11.49 & 20 & 27.59 & 48 & 48.28 & 84 & 8.62 & 15 \\
\hline $\begin{array}{l}\text { Adding comments on the } \\
\text { information shared on } \\
\text { the blogs contributes to } \\
\text { my learning. }\end{array}$ & 8.05 & 14 & 17.82 & 31 & 27.59 & 48 & 37.36 & 65 & 9.20 & 16 \\
\hline $\begin{array}{l}\text { My friends' comments on } \\
\text { the information I share } \\
\text { contribute to my } \\
\text { learning. }\end{array}$ & 7.47 & 13 & 21.26 & 37 & 25.86 & 45 & 37.93 & 66 & 7.47 & 13 \\
\hline
\end{tabular}

As for the opinions of the pre-service teachers regarding motivation, $45.40 \%$ of them $(\mathrm{N}=79$ ) believe that use of blogs increase motivation towards courses. In a similar study about use of blogs in Information and Communication Technologies, majority of the pre-service teachers (84\%) reported that use of blogs increased their motivation (Göktaş \& Demirel, 2012). Cakir (2013) stated that one of the focal points of the studies in the literature about the use of blogs by pre-service teachers was that the use of blogs increased motivation towards the use of technology. The opinions of pre-service teachers in these studies show that increasing the use of blogs in the courses would yield favorable results in terms of the solution of educational problems thanks to its motivating potential.

In addition, according to the results, $68.3 \%$ of the pre-service teachers $(\mathrm{N}=119)$ believe that use of blogs in courses ensure active participation in the courses. In addition to providing 
active participation in the classroom activities (Cakir, 2013), Lin et al. (2006) expresses that blogs are suitable tools for the socialization of students in online courses. In line with these results, blogs can be used as an efficient tool in the case that active participation of students cannot be provided. Through organizing course activities with the help of blogs, majority of the students can be encouraged to actively participate in the courses.

Besides, $59.7 \%$ of the pre-service teachers $(\mathrm{N}=104)$ reported that they found the use of blogs useful for the improvement of writing skills. In the qualitative study of Tekinarslan (2008), it is expressed that studying with blogs improves the writing skills of the students according to the opinions of the students. Liou (2007) and Şimşek (2010) also suggest that use of blogs contributes to the academic writing skill of students. This potential of blogs can be benefited in Turkish or foreign language courses and blogs can be used as a platform on which students improve their writing skills in such courses.

As for the evaluation of the use of blogs in group works, $73.52 \%$ of the pre-service teachers $(\mathrm{N}=128)$ reported that they found it efficient for group work. Similarly, Atıcı and Özmen (2011) state that intensive use of blogs enhances the sense of being a community, which is an important variable for group work. Petersen, Divitini, and Chabert (2008) and Wang, Huang, Jeng and Wang (2008) emphasize the importance of blogs in creating online communities. Therefore, use of blogs will be productive with many teaching methods that include group work. Blogs can constitute a different teaching environment where group works are carried out.

Pre-service teachers $(56.9 \%, \mathrm{~N}=99)$ believe that use of blogs improve critical thinking skills. In the light of this result, critical thinking skills of the students can be improved by the use of blogs in various teaching activities. However, according to Babur (2010), the use of blogs has no significant effect on critical thinking skills. On the other side, qualitative data analysis of the study gave totally opposite results. The relationship between blogs and critical thinking was supported by various studies (Cakir, 2013; Godwin-Jones, 2006; Prestridge, 2012; Yang, 2009).

According to the data about commenting, which is one of the most important components of blogs, $46.56 \%$ of the pre-service teachers $(\mathrm{N}=81)$ believe that adding comments on the shared information on blogs contributes to learning and $45.4 \%$ of them $(\mathrm{N}=79)$ think that their friends' comments contribute to their learning. Blogs are expressed as tools supporting social and individual learning (Lin et al., 2006). The results of the research by Babur (2010) suggest that comments of students in blogs are important in terms of student development. Despite the majority in this research is not of the opinion that commenting on blogs contribute to learning, blogs can be used in various activities as they provide the opportunity to comment, which plays an important role from the perspective of constructivist learning approach.

The results in Table 7 expose that all participants show positive attitudes towards the use of blogs in learning and teaching activities. The fact that no statistically significant differences were found between the two groups in all items shown in Table 7 explains that the pre-service teachers are in favor of the use of blog applications to improve critical thinking. Moreover, being aware of the importance of blogs, both male and female teachers use blogs to improve group work. They believe that using blogs increases the pre-service teachers' motivation and enhances their learning. 
Table 7. Gender Differences about the Use of Blogs

\begin{tabular}{|c|c|c|c|c|c|c|}
\hline \multirow[t]{2}{*}{ Item } & \multicolumn{2}{|c|}{ Male } & \multicolumn{2}{|c|}{ Female } & \multirow[b]{2}{*}{$\mathrm{t}$} & \multirow[b]{2}{*}{$p$} \\
\hline & $\mathrm{x}$ & SS & $\mathrm{x}$ & SS & & \\
\hline $\begin{array}{l}\text { The use of blogs contributes to my learning } \\
\text { process. }\end{array}$ & 3.51 & 1.05 & 3.50 & 1.00 & 0.08 & 0.93 \\
\hline $\begin{array}{l}\text { The use of blogs increases my motivation } \\
\text { towards courses. }\end{array}$ & 3.33 & 1.12 & 3.18 & 1.08 & 0.81 & 0.41 \\
\hline $\begin{array}{l}\text { Adding comments on the information shared } \\
\text { on the blogs contributes to my learning. }\end{array}$ & 3.49 & 1.12 & 3.70 & 0.91 & 1.24 & 0.21 \\
\hline $\begin{array}{l}\text { My friends' comments on the information I } \\
\text { share contribute to my learning. }\end{array}$ & 3.40 & 1.19 & 3.54 & 1.00 & 0.77 & 0.43 \\
\hline $\begin{array}{l}\text { The use of blogs in courses enables active } \\
\text { participation in the courses. }\end{array}$ & 3.84 & 0.97 & 3.80 & 0.82 & 0.30 & 0.75 \\
\hline $\begin{array}{l}\text { The use of blogs contributes to the } \\
\text { improvement of my writing skills. }\end{array}$ & 3.58 & 0.94 & 3.42 & 0.94 & 0.97 & 0.33 \\
\hline The use of blogs is effective for group work. & 3.31 & 1.04 & 3.03 & 0.96 & 1.64 & 0.10 \\
\hline $\begin{array}{l}\text { The use of blogs improves my critical thinking } \\
\text { skills. }\end{array}$ & 3.27 & 1.11 & 3.20 & 1.05 & 0.35 & 0.72 \\
\hline
\end{tabular}

Table 8 shows opinions of pre-service teachers about the use of blogs in future. Accordingly, $39.08 \%$ of the pre-service teachers $(\mathrm{N}=68)$ believe that use of blogs enhance academic success. These results are in line with the study of Ladyshewsky and Gardner (2008). Babur (2010) found that there was no significant difference between academic achievement of the students that use blogs and those that do not use. In the light of these results, it can be alleged that the use of blogs does not have a big influence on academic success by itself.

Pre-service teachers $(47.7 \%, \mathrm{~N}=83)$ believe that blogs should be also used in other courses. In other words, almost half of the students think that blogs should be also used in other courses while the other half thinks the opposite. This situation may be resulting from the individual differences between students. In the study of Cakir (2013), the "student satisfaction" average, which also included the opinions of pre-service teachers about the use of blogs in other courses, was found to be 3.38 on a 5-point scale.

As for the results about the use of blogs in daily life, $40.81 \%$ of the subjects $(\mathrm{N}=71)$ expressed that they would use the blogs (which they created in the scope of the course) in their daily lives. However, the students who are expressed as digital local are inclined to use these technologies in their daily lives $(\mathrm{Ng}, 2012)$. On the other hand, $58.62 \%$ of them $(N=103)$ consider to use blogs to support learning-teaching activities in their professional lives. This shows that the pre-service teachers may use blogs in their future courses in order to support their learning and teaching activities while they are practicing their profession. When the integration of information technologies into education is taken into account, it would be useful to update curriculums to fulfil these ideas of the pre-service teachers. 
Tablo 8.Opinions of Pre-service Teachers about the Use of Blogs in Future

\begin{tabular}{|c|c|c|c|c|c|c|c|c|c|c|}
\hline \multirow[t]{2}{*}{ Questions } & \multicolumn{2}{|c|}{$\begin{array}{c}1 \\
\text { (Totally } \\
\text { Disagree) }\end{array}$} & \multicolumn{2}{|c|}{$\begin{array}{c}2 \\
\text { (Disagree) }\end{array}$} & \multicolumn{2}{|c|}{$\begin{array}{c}3 \\
\text { (Neutral) }\end{array}$} & \multicolumn{2}{|c|}{$\begin{array}{c}4 \\
\text { (Agree) }\end{array}$} & \multicolumn{2}{|c|}{$\begin{array}{c}5 \\
\text { (Totally } \\
\text { Agree) }\end{array}$} \\
\hline & $\%$ & $\mathrm{~F}$ & $\%$ & $\mathrm{~F}$ & $\%$ & $f$ & $\%$ & $f$ & $\%$ & $\mathrm{f}$ \\
\hline $\begin{array}{l}\text { I believe that use of } \\
\text { blogs will enhance my } \\
\text { academic success. }\end{array}$ & 5.75 & 10 & 21.84 & 38 & 33.33 & 58 & 34.48 & 60 & 4.60 & 8 \\
\hline $\begin{array}{l}\text { I think that blogs } \\
\text { should be used in other } \\
\text { courses, as well. }\end{array}$ & 7.47 & 13 & 18.39 & 32 & 26.44 & 46 & 40.23 & 70 & 7.47 & 13 \\
\hline $\begin{array}{l}\text { I believe that I will use } \\
\text { my course-related } \\
\text { blogs actively in my } \\
\text { daily life, too. }\end{array}$ & 8.62 & 15 & 18.39 & 32 & 32.18 & 56 & 36.21 & 63 & 4.60 & 8 \\
\hline $\begin{array}{l}\text { I believe that I will } \\
\text { benefit from blogs to } \\
\text { support learning- } \\
\text { teaching activities in } \\
\text { my professional life. }\end{array}$ & 5.17 & 9 & 8.62 & 15 & 27.59 & 48 & 50 & 87 & 8.62 & 15 \\
\hline
\end{tabular}

The findings presented in Table 9 displays that both male and female prospective teachers agree on the benefits of using blogs in their classes since there existed no statistically significant differences between the two groups. Both male and female prospective teachers admit the important role that blogs play and they indicate that they will use blogs in their learning and teaching activities.

Table 9. Gender Differences about the Use of Blogs in Future

\begin{tabular}{|c|c|c|c|c|c|c|}
\hline \multirow[t]{2}{*}{ Item } & \multicolumn{2}{|c|}{ Male } & \multicolumn{2}{|c|}{ Female } & \multirow{2}{*}{$\mathrm{t}$} & \multirow[b]{2}{*}{$p$} \\
\hline & $x$ & SS & $x$ & SS & & \\
\hline $\begin{array}{l}\text { I believe that use of blogs will enhance my } \\
\text { academic success. }\end{array}$ & 3.09 & 0.87 & 3.10 & 1.08 & 0.06 & 0.94 \\
\hline $\begin{array}{l}\text { I think that blogs should be used in other } \\
\text { courses, as well. }\end{array}$ & 3.44 & 0.89 & 3.50 & 0.97 & 0.31 & 0.75 \\
\hline $\begin{array}{l}\text { I believe that I will use my course-related blogs } \\
\text { actively in my daily life, too. }\end{array}$ & 3.64 & 1.17 & 3.84 & 0.90 & 1.13 & 0.25 \\
\hline $\begin{array}{l}\text { I believe that I will benefit from blogs to support } \\
\text { learning-teaching activities in my professional } \\
\text { life. }\end{array}$ & 2.87 & 1.25 & 2.95 & 1.20 & 0.41 & 0.68 \\
\hline
\end{tabular}




\section{Results and Conclusion}

Recently, effective use of technology has a particular importance for Turkish in-service and pre-service teachers, who will play an important role to integrate computer technology into the FATIH project of the Turkish government. The FATIH project, announced in 2010, requires teachers to adapt new changes in technology and to implement technology as well. The administrators also stress the main role of teachers in the project who would act as a guide regarding the use of IT technologies (Dursun, Kuzu, Kurt, Güllüpınar, \& Gültekin, 2013). Thus, it is important to investigate whether teachers have the necessary information and skills to be able to use those technologies effectively. This study, which was carried out to get the opinions of pre-service teachers about the use of blogs, revealed the views of pre-service teachers about the benefits of the use of blogs. It was discovered that the pre-service teachers generally found it easy to use blogs. As this web technology does not require any programming or web design knowledge, it is easy to teach and learn. Therefore, the educators who desire to use web technologies during, before or after the teaching process may prefer and easily use blogs.

According to Çiftçi, Taşkaya, and Alemdar (2013), that the FATIH Project will affect students' writing, reading and speaking skills is the biggest disadvantage of the project. In their study which aimed to determine the viewpoints of classroom teachers about the FATIH project found that lack of information about using computer technology will make it difficult to implement the project. In this study, however, it was found that according to the opinions of the pre-service teachers about the benefits of the use of blogs, the use of blogs contributed to learning, increased active participation in the courses, contributed to the improvement of writing skills, was effective for group work, and improved critical thinking skills. Blogs can be used on different platforms (computer, tablet etc.) to ensure active participation in lessons, increase learning, and improve critical thinking skills on the tablet computers which will be distributed to 17 million students and approximately one million teachers and administrators in the FATIH project. Blogs can be a different option for teachers especially in the lessons that aim to increase writing skills. Furthermore, blogs can be used as an auxiliary tool of learning for effective group works.

As for the opinions that the use of blogs increase motivation towards courses and that making comments on the information in blogs and getting comments for the information shared on the blogs contribute to the learning process, there was no majority among the pre-service teachers. Considering these results, other factors to provide motivation for the use of blogs in educational activities can be included, and other activities that will contribute to learning can be used in addition to commenting on the information during learning. Furthermore, majority of the pre-service teachers did not believe that the use of blogs would increase academic success. As for the opinion that blogs should also be used in other courses, there was no majority among pre-service teachers.

According to the FATIH project, teachers will be able to instantly access any document around the world they may need for their classes, projecting it on the interactive smart board. The project will also facilitate long-distance learning programs while encouraging a gradual transition to e-textbooks and other electronic-learning materials for each class (Turkish Ministry of National Education, 2012). In this sense, instead of being used alone, blogs can be used as tools to enrich learning together with other tools, platforms or materials on tablet 
computers. Similarly, few of the pre-service teachers considered to use the blogs they created for the lessons in their daily lives. However, a significant part of the pre-service teachers considered to benefit from blogs in order to supports learning and teaching activities in their professional lives. According to this result, despite the educators do not prefer using blogs in their daily lives, they may use them to create a difference in their teaching activities. Kurt, Kuzu, Dursun, Güllüpınar, and Gültekin (2013), in their study with the teachers whose views were revealed via focus group interviews, reported that the teachers had problems especially with content and that the current content failed to meet their needs. In this respect, for teachers, using blogs might be an opportunity to provide rich materials in teaching and reaching the information easily on the tablet computers.

In light of the obtained results, further research can be conducted on the use of blogs by students with different individual characteristics especially by considering the requirements of the FATIH project. Such studies may examine students from different age groups and with different learning styles. Moreover, use of blogs in different methods, lessons, topics or areas and on different technologies (laptop, tablet etc.) may yield different results. Therefore, further research can be done to determine at which areas (natural sciences, mathematics, social sciences, linguistics), at which courses (practical, theoretical) and at which teaching methods the use of blogs are more effective. Especially considering the contribution of blogs to writing skills, studies can be performed on groups with different characteristics in language training. Furthermore, research can be done to compare the use of blogs in group work and the individual use of blogs and to determine how these two situations affect different variables (success, motivation, attitude, etc.).

\section{References}

Arslan, R. Ş. \& Kızıl, A. (2010). How can the use of blog software facilitate the writing process of English language learners? Computer Assisted Language Learning, 23(3), 183-197.

Atıcı, B. \& Özmen, B. (2011, May). Effect of the blog use of a sense of class community. Paper Presented at International Educational Technologies Symposium. Istanbul.

Babur, A. (2010). At Network Diary Environment of Information Technology course in Bolu Gazipaşa $5^{\text {th }}$ Grade Primary School, the effect of studying "Here I go Broadcasting" unit on critical thinking, the retention and academic success (Unpublished master's thesis). Graduate School of Educational Sciences, Gazi University, Ankara.

Cakir, H. (2013). Use of blogs in pre-service teacher education to improve student engagement, Computers \& Education, 68, 244-252.

Churcill, D. (2009). Educational applications of Web 2.0: Using blogs to support teaching and learning. British Journal of Educational Technology, 40(1), 179-183.

Çiftçi, S., Taşkaya, S. M. \& Alemdar, M. (2013). The opinions of classroom teachers about FATIH project. Elementary Education Online, 12(1), 227-240

Davis, M. (2008). Semantic wave 2008 report: Industry roadmap to web 3.0 and multibillion dollar market opportunities. Retrieved on 13 March from http://www.project10X.com.

Demirel, T. (2010). Teachers' feedback on instructional use of blogs (Unpublished master's thesis). Graduate School of Educational Sciences, Atatürk University, Erzurum. 
Duffy, P. \& Bruns, A. (2006). The use of blogs, wikis and RSS in education: A conversation of possibilities. Proceedings Online Learning and Teaching Conference (pp.31-38). Brisbane.

Dursun, Ö.Ö., Kuzu, A., Kurt,A. A., Güllüpınar, F. \& Gültekin, M. (2013). Views of school administrators' on FATIH project's pilot implementation process. Trakya University Journal of Education, 3(1), 100-113.

Efimova, L. \& Moor, A. (2005). Beyond personal web publishing: An exploratory of conversational blogging practices. Paper presented at the 38th Annual Hawaii International Conference on System Sciences. Hawaii.

Ferdig, R.E. \& Trammell, K.D. (2004). Content delivery in the blogosphere. T H E Journal. 31(7), 12-20.

Fullan, M. G. (1990). Staff development, innovation, and institutional development. In B. Joyce (Ed.), Changing school culture through staff development. Alexandria, VA: ASCD.

Girgin, M. K. (2009). Research report of blog writing in Turkey. Retrieved on 5 April 2009 from http://murat.blogevi.org.

Godwin-Jones, R. (2006). Emerging technologies. Tag clouds in the blogosphere: Electronic literacy and social networking. Language Learning \& Technology, 10(2), 8-15.

Göktaş, Y. \& Demirel, T. (2012). Blog-enhanced ICT courses: Examining their effects on preservice teachers' ICT competencies and perceptions. Computers \& Education, 58, 908917.

Hou, H.T, Chang, K. E. \& Sung, Y. T. (2011). A longitudinal analysis of the behavioural patterns in teachers using blogs for knowledge interactions. British Journal of Educational Technology, 42(2), 34-36.

Huffaker, D. (2005). The Educated Blogger: Using weblogs to promote literacy in the classroom. AACE Journal, 13(2), 91-98.

Jones, S. J. (2006). Blogging and ESL writing: A case study of how students responded to the use of weblogs as a pedagogical tool for the writing process approach in a community college ESL writing class. Dissertation. The Graduate School of the University of Texas, Austin.

Kenndey, K. (2003). Writing with Web logs. Technology \& Learning. February 2003. Retrieved on March 3, 2013 from http://web2play.pbworks.com/f/Post+Writing+with+Web+ Logs+copy.pdf

Kim, H. N. (2008). The phenomenon of blogs and theoretical model of blog use in educational contexts. Computers \& Education, 51, 1342-1352.

Kurt, A. A., Kuzu, A., Dursun, Ö.Ö., Güllüpınar, F. \& Gültekin, M. (2013). Evaluation of the pilot application process of FATIH project: Teachers' views. Journal of Instructional Technologies \& Teacher Education, 1(2), 1-23.

Ladyshewsky, R. \& Gardner, P. (2008). Peer assisted learning and blogging: a strategy to promote reflective practice during clinical fieldwork. Australasian Journal of Educational Technology, 24(3), 241-257. 
Liou, H. C. (2007). Toward autonomous learning of academic English writing: What can electronic disciplinary portfolios offer? In S. Chang (Ed.), Proceedings of the 24th International Conference on English Teaching and Learning in the ROC (pp. 273-284). Taipei: Taiwan ELT Publishing.

Lin, W.-J., Yueh, H.-P., Liu, Y.-L., Murakami, M., Kakusho, K. \& Minoh, M. (2006). Blog as a tool to develop e-learning experience in an international distance course. Proceedings of the Sixth IEEE International Conference on Advanced Learning Technologies (ICALT'06).

Martindale, T. \& Wiley, D.A. (2004). An introduction to teaching with weblogs. Draft Copy. Retrieved on 18 March 2013 from http://citeseerx.ist.psu.edu/viewdoc/download? doi=10.1.1.137.5486\&rep=rep1\&type $=p d f$

Martinez, M. \& Jagannathan, S. (2010). Social Networking, adult learning success and Moodle. In T. T. Kidd \& J. Keengwe (Eds.), Adult learning in the digital age: Perspectives on online technologies and outcomes (pp.68-80). New York: Hershey.

Ministry of National Education (MEB). (2008). Teacher qualifications: General and specific qualifications of teaching profession. Ankara: General Directorate of Teacher Training and Education.

Ministry of National Education (MEB). (2012). Fatih Project. Retrieved on 8 April 2013 from http://fatihprojesi.meb.gov.tr

Ng, W. (2012). Can we teach digital natives digital literacy? Computers \& Education, 59, 10651078.

Oreilly, T. (2007). What is Web 2.0: Design patterns and business models for the next generation of software. Communications \& Strategies, 1, 17-37.

Petersen, S. A., Divitini, M., \& Chabert, G. (2008). Identity, sense of community and connectedness in a community of mobile language learners. ReCall, 20, 361-379.

Prestridge, S. (2013). The beliefs behind the teacher that influences their ICT practices. Computers \& Education, 58, 449-458.

Rice, A. (2003). The use of blogs in the 2004 presidential election. Baltimore, MD: The Johns Hopkins University.

Richardson, W. (2006). Blogs, wikis, podcasts, and other powerful web tools for classrooms. Thousand Oaks. CA: Corwin Press.

Şenel, H. C. \& Seferoğlu, S. S. (2009). Applications in education blog: Examples of primary information technology course. Paper presented at 9th International Educational Technology Conference (IETC2009). Ankara.

Slevin, J. (2000). The Internet and society. London, UK: Polity.

Şimşek, Ö. (2010). The effect of weblog (blog) students' writing performance. 2nd World Conference on Educational Sciences, WCES-2010. Procedia - Social and Behavioral Sciences, 2(2), 953-958.

Tekinarslan, E. (2008). Blogs: A qualitative investigation into an instructor and undergraduate students' experiences. Australasian Journal of Educational Technology, 24(4), 402-412.

Tekinarslan, E. \& Gürer, M. D. (2011). Abant Izzet Baysal University CEIT students' views on network logs as knowledge sharing and web publishing tools. Kastamonu Education Journal, 19(3), 887-902. 
Yang, S. H. (2009). Using blogs to enhance critical reflection and community of practice. Educational Technology \& Society, 12(2), 11-21.

Yi-Hui, C. (2013). Using a combined AHP and PLS path modeling on blog site evaluation in Taiwan. Computers in Human Behavior, 29, 1325-1333.

Wang, S. (2009). Blogs in Education. In M. Pagani (Eds.). Encyclopedia of multimedia technology and Networking ( $2^{\text {nd }}$ ed.). IGI Global.

Wang, K. T., Huang, Y. M., Jeng, Y. L. Wang, T. I. (2008). A blog-based dynamic learning map. Computers \& Education, 51, 262-278

West, R. E., Wright, G. W., Gabbitas, B., \& Graham, C. R. (2006). Reflections from the introduction of blogs and RSS feeds into a pre-service instructional technology course. TechTrends, 50(4), 54-60.

Correspondence: Mehmet Akif Ocak, Associate Professor and Director, Distance Education Center, Gazi University, Besevler, Ankara, Turkey. 